\title{
EUROCRIM 2021
}

\section{1. godišnja konferencija Europskog udruženja za kriminologiju "Criminology in a time of pandemic", 8. - 10. rujna 2021., online konferencija ${ }^{1}$}

\author{
UDK: 343.9:061.2(4)(047) \\ DOI: 10.3935/zpfz.71.34.10
}

U skladu s globalnom epidemijom uzrokovanom širenjem korona virusa, u mrežnom izdanju održana je dvadeset i prva godišnja konferencija Europskog udruženja za kriminologiju (dalje u tekstu: ESC). ESC je najveće europsko kriminološko udruženje, osnovano 2000. godine s ciljem stvaranja platforme kroz koju bi se povezale osobe u Europi koje su aktivno uključene u istraživanje, podučavanje i/ili praksu iz područja kriminologije. U međuvremenu konferencija je prerasla u platformu i šireg dosega pa je tako svake godine posjećuju i vrhunski stručnjaci iz SAD-a, Kanade, Japana i sl. Godišnje ESC-ove konferencije pružaju priliku članovima da predstave rezultate vlastitih istraživačkih projekata, ali i da steknu informacije o drugim projektima i istraživanjima koja se provode te o najnovijim spoznajama i aktualnim trendovima u kriminološkom području. Usprkos činjenici da mrežna izdanja nikad ne mogu zamijeniti stvarni ljudski kontakt ni prenijeti energiju i atmosferu akademskih diskusija, ovogodišnja online konferencija pokazala je da i na daljinu može biti jednako dobro i na kvalitetan način prenijeti zanimljive teme, nove spoznaje i izazovna pitanja. Konferencija je okupila oko 850 sudionika iz cijeloga svijeta koji su na više od 200 panela prezentirali svoje radove, istraživanja i/ili projekte iz najaktualnijih područja kriminologije, ali i srodnih područja (kaznenog prava, viktimologije, penologije i dr.). Uz to, brojne teme bile su posvećene i već tradicionalnim temama iz područja kaznenog pravosuđa, politike suzbijanja kažnjivog ponašanja, kažnja-

Autorice prikaza sudjelovale su na konferenciji u okviru CroViMo projekta (www. violence-lab.eu) i projekta "Projekt razvoja karijera mladih istraživača - izobrazba novih doktora znanosti” (ESF DOK-2018-01-6494), sufinanciranih od strane Hrvatske zaklade za znanost i Pravnog fakulteta Sveučilišta u Zagrebu te Europskog socijalnog fonda. 
vanja, zatvorskog sustava, a u takvom multidisciplinarnom okružju bilo je riječi i o nasilju i rodnoj ravnopravnosti, ljudskim pravima, ali i zaštiti okoliša. Na ESC-ovoj konferenciji svake godine predstavljaju se i inovativne teme i pravci u području kriminologije (npr. povezanost kriminala i glazbe, kriminologija iz perspektive feminizma i sl.), što dokazuje kako je kriminologija dinamično područje, ali i vrlo kompleksan perpetuum mobile. Dodatno, neizostavna je tema ove godine bila i propitivanje utjecaja pandemije na društvo i kriminal, stoga je i naziv ovogodišnje konferencije primjeren pandemijskim vremenima - Criminology in a time of pandemic. U tom smislu, kao i svake godine, konferencija je iznjedrila zanimljive akademske diskusije, nove znanstvene teme, izazovne istraživačke fokuse i najaktualnija pitanja iz područja kriminologije, i sve to u multikulturnom i multidisciplinarnom okružju i time potvrdila svoj status najuspješnije europske kriminološke konferencije.

Nakon uvodnih riječi dobrodošlice bivše predsjednice prof. dr. Lesley McAra konferenciju je otvorio Aleksandras Dobryninas, aktualni predsjednik ESC-a, ujedno i profesor na Sveučilištu u Vilniusu. Nakon kratkih pozdravnih govora uslijedilo je svečano dodjeljivanje ESC-ovih nagrada. Nagradu za ESC-ova mladog kriminologa 2021. godine dobila je dr. sc. Anita Lavorgna, izvanredna profesorica na Katedri za sociologiju, socijalnu politiku i kriminologiju Sveučilišta u Southamptonu (Velika Britanija), dok su nagradu za najbolji znanstveni članak u Europskom časopisu kriminologije (European Journal of Criminology Best Article of the Year 2020 Award) odnijeli Janna Verbruggen, Arjan Blokland, Amanda L. Robinson i Christopher D. Maxwell za rad The relationship between criminal behaviour over the life-course and intimate partner violence perpetration in later life, objavljen u izdanju 17/6 (str. 784 - 805). ESC-ova nagrada za najbolju knjigu (ESC Book award) pripala je škotskom kriminologu prof. Fergusu McNeillu za knjigu Pervasive Punishment: Making Sense of Mass Supervision, koji je svoju knjigu i predstavio. ESC-ova nagrada za doprinos europskoj kriminologiji (European Criminology Award) dodijeljena je prof. Loraine Gelsthorpe za životni doprinos razvoju europske kriminologije. Prof. Gelsthorpe obratila se sudionicima konferencije govorom zahvale, čime je završilo plenarno otvaranje i dodjela nagrada.

Drugog dana konferencije održana su dva panela u organizaciji ESC-ove radne grupe European Violence Monitor. U okviru tih dvaju panela devet članova istraživačke skupine projekta "Hrvatski monitor nasilja - istraživanje pojavnih oblika, uzroka i procesuiranja delinkventnog nasilja s fokusom na zaštiti posebno ranjivih skupina žrtava" (Violence Research Lab) održalo je ukupno osam prezentacija. U fokusu obaju panela bilo je nasilje, a izlagači su prikazali raznolikost fenomena nasilja iz različitih praktičnih perspektiva (policijski pristup prevenciji nasilja, uloga forenzike kod delikata nasilja) te iz teorijskih perspektiva (propitivanje uspješnosti kaznenog prava u prevenciji nasilja, ekonomski troškovi kriminala), 
ali i upozorili na empirijske podatke nekih od fenomenološki zanimljivih oblika nasilja uz propitivanje njihovih etioloških specifičnosti prije, ali i za vrijeme koronakrize (obiteljsko nasilje, masovna pucnjava u školama u SAD-u).

Prvim panelom Violence Research Lab I predsjedala je asistentica na projektu Petra Šprem s Pravnog fakulteta Sveučilišta u Zagrebu, a nakon najave panel je svojim izlaganjem otvorila doc. dr. sc. Ruža Karlović s Visoke policijske škole u Zagrebu. R. Karlović predstavila je model suradnje policije i zajednice (engl. community policing) koji ima cilj ojačati sigurnost društva. Istaknula je kardifski model (Cardiff model) kao jedan od najučinkovitijih europskih modela prevencije, koji prikupljanjem i analizom različitih podataka prikupljenih od strane policije, bolnica, sudova i sl. kreira strategiju za podizanje razine sigurnosti u Engleskoj. Kao dokaz da navedeni model funkcionira, Karlović navodi da je Cardiff zabilježio smanjenje od $32 \%$ policijskih prijava nasilja, uz istodobno smanjenje prijama u bolnicu kao žrtva nasilja za $42 \%$. Da bi se kvalitetno proveo Cardiff model u određenoj zajednici, važno je da u zajedničkom programu prevencije nasilja sudjeluju svi, naglasila je Karlović, od policije, sudova, bolnica, gradonačelnika, mjesne zajednice, sigurnosne službe, ali i privatne kompanije, škole i nevladine udruge.

Uslijedila je prezentacija dr. sc. Marije Baković i dr. sc. Davora Mayera sa Zavoda za sudsku medicinu i kriminalistiku Medicinskog fakulteta Sveučilišta u Zagrebu. Temu važnosti i značenja forenzičkih nalaza i mišljenja u kaznenom postupku predstavila je dr. sc. Marija Baković. Ona je uvodno objasnila čime se bavi klinička sudska medicina i koji se podaci prikupljaju kroz forenzička izvješća. U nastavku izlaganja istaknula je važnost takvih izvješća u kaznenom postupku koja mogu usmjeriti odluku suda o tome je li se dogodilo nasilje, na koji način, je li optuženik kriv ili nije. Samo kvalitetna procjena i dokumentiranje fizičkih ozljeda može, naglasila je Baković, doprinijeti ispravnoj odluci suda. Međutim, istaknula je i da su u stvarnosti forenzička izvješća nerijetko nepotpuna i sadržajno nedostatna jer prvi pregled ozlijeđene osobe često ne rade vještaci već djelatnici hitne službe, pedijatri ili pak kirurzi, i to u dijagnostičke i terapeutske svrhe, dok se kod manjih ozljeda često ni ne provodi naknadno vještačenje. U tim slučajevima, rekla je, zbog potrebe hitne reakcije, ali i nedostatka edukacije liječnika nastaju takva izvješća. Zaključno, Baković je iznijela nekoliko prijedloga koji bi mogli pridonijeti kvalitetnijim forenzičkim izvješćima poput važnosti edukacije liječnika o tome koliko i što znače potpuna, kvalitetna i detaljna izvješća za kazneni postupak, jasno artikuliranje važnosti izvješća žrtvi nasilja od strane policije, dok bi se tužitelji trebali koristiti izvješćima sudskih medicinara kad god je to moguće i pritom se s njima konzultirati ako je to potrebno.

Treća tema obuhvatila je aktualni istraživački fokus svih kriminologa posljednjih godinu dana - nasilje za vrijeme koronakrize. Izlaganje je održala dr. sc. 
Reana Bezić s Pravnog fakulteta Sveučilišta u Zagrebu. U izlaganju je analiziran utjecaj epidemioloških mjera nametnutih u svrhu zaustavljanja širenja korona virusa na nasilnu delinkvenciju. Bezić je uvodno prikazala glavne kriminološke teorije koje se bave utjecajem društva na etiologiju nasilja poput Durkheimove teorije anomije i teorije rutinske aktivnosti Cohena i Felsona. Ukupan kriminal u Republici Hrvatskoj je u padu, ali, istaknula je Bezić, ipak postoje razlike ovisno o vrsti delinkvencije. U izlaganju je predstavila ključne statističke podatke na kojima je vidljivo da su kaznena djela ubojstva, silovanja, krađe i razbojništva u padu ako promatramo broj prijavljenih osoba u 2020. godini u odnosu na 2019. godinu. S druge strane, u porastu su kibernetičko nasilje i prenošenje zaraznih bolesti, što je i logično, objasnila je Bezić, s obzirom na to da su nametnute epidemiološke mjere svakodnevicu "prebacile” iz stvarnog u mrežno okružje, a prenošenje zaraznih bolesti bilo je posebno aktualno pri kršenju epidemioloških mjera. Zaključno, Bezić je istaknula da sve društvene krize imaju snažan utjecaj na kriminalitet u cjelini, pa i na nasilne delikte, te da će se pravi učinak koronakrize moći vidjeti s vremenskim odmakom.

Panel je zatvoren intrigantnom tematikom "troškova kriminala”. Pogled na nasilje s ekonomskog aspekta predstavio je dr. sc. Vedran Recher s Ekonomskog instituta u Zagrebu. On je uvodno naglasio da je, u sklopu kvalitetne politike suzbijanja kriminala, iznimno važno znati koliko države zapravo kriminal košta. Podcijenjena tema u kriminologiji, nastavio je Recher, može biti važna i za mjerenje uspješnosti pravosudnog sustava te izračun troškova ulaganja potrebnih sredstava u suzbijanje delinkvencije. Recher je upozorio da, iako je nemoguće izračunati točan trošak kriminala, na temelju nekoliko modela moguće je napraviti procjenu, razlikujući pritom izravne i neizravne ekonomske efekte kriminala. Zaključno, na temelju modela koji je primijenio Czabański za Poljsku, Recher prikazuje izračun da ukupni izravni i neizravni troškovi kriminala u Hrvatskoj iznose približno milijardu kuna.

Drugi panel Violence Research Lab 2 moderirala je dr. sc. Reana Bezić s Pravnog fakulteta Sveučilišta u Zagrebu. Panel je otvoren prezentacijom Petre Šprem, asistentice s Pravnog fakulteta Sveučilišta u Zagrebu. Panel je otvorila temom koja je, kako je navela, više teorijsko-filozofska, ali i sve važnija u kriminološkom diskursu posljednjih godina. Riječ je o traženju odgovora na pitanje koliko je kazneno pravo uspješan preventivni mehanizam za suzbijanje obiteljskog nasilja. Odgovor na to pitanje, naglasila je Šprem, treba promatrati kroz dva ključna aspekta: etiološki, u smislu uzroka koji dovode do obiteljskog nasilja, i drugi, preventivni, u smislu odgovora na pitanje imaju li institucionalni mehanizmi djelotvoran preventivni mehanizam. Izložila je glavne uzročnike obiteljskog nasilja poput alkoholizma, manjka samokontrole, zlostavljanja u djetinjstvu, apatije, siromaštva i sl. uz naglasak da je više riječ o rizičnim faktorima za 
pojavu nasilja jer u etiologiji nasilja ne postoje konkretni uzroci. Što se tiče uspješnosti preventivne uloge kaznenog prava, Šprem je istaknula kako posljednja istraživanja upućuju na to da je, od svih oblika socijalne kontrole, kazneno pravo najmanje uspješan barem kada je riječ o deliktima nasilja. Izlaganje je završeno uz nekoliko konkretnih prijedloga o preveniranju nasilja kroz druge izvanpravne mehanizme poput edukacije o zdravim međuljudskim odnosima od najranije dobi, stjecanja društvenih vještina i razvijanja empatije u vrtićima i školama, tečajeva za roditelje i parove, obiteljskih programa potpore, posjeta obiteljima, ekonomske podrške mladim parovima i obiteljima, dostupnosti psihološke podrške i sl.

Sljedeće izlaganje također je bilo posvećeno temi obiteljskog nasilja u svjetlu koronakrize. Izlaganje je održala dr. sc. Mirjana Kondor-Langer s Policijske akademije u Zagrebu. U izlaganju je bilo riječi o obiteljskom nasilju i njegovoj incidenciji u vrijeme koronakrize. M. Kondor-Langer pritom je prezentirala policijsku statistiku koja pokazuje da je došlo do pada u općem kriminalitetu (pad od 9,5 \%), dok je u slučaju obiteljskog nasilja u 2020. godini došlo do porasta za čak 39,2 \%. Uz napomenu da je došlo do razlike u učestalosti obiteljskog nasilja kao prekršaja i obiteljskog nasilja kao kaznenog djela, iznijela je podatak da se broj žrtava prekršajnog djela obiteljskog nasilja smanjio 7,4 \%, dok je broj žrtava kaznenog djela obiteljskog nasilja porastao 39,2 \%. Kao zaključak Kondor-Langer navela je da, premda je broj kaznenih djela u porastu u godini kada je počela korona kriza (2020.) u odnosu na godinu prije, valja imati na umu i izmjene kaznenog i prekršajnog zakonodavstva u području obiteljskog nasilja koje su iste godine stupile na snagu (1. siječnja 2020.) i možda doprinijele ovakvom porastu kaznenih djela, odnosno smanjenju prekršajnih djela obiteljskog nasilja.

Pretposljednje izlaganje u ovom panelu održao je dr. sc. Pero Mihaljević iz Vijeća za nacionalnu sigurnost, koji se osvrnuo na problem radikalizacije i ekstremizma. Bez obzira na to što Hrvatska nema problem s kaznenim djelom terorizma, kazao je, nedavni slučaj pucnjave na zgradu Sabora na Markovu trgu opet je podsjetio na temu terorizma, ekstremizma i radikalizma te druga sigurnosna pitanja. Uvodno je Mihaljević istaknuo da ne postoji jedinstvena definicija radikalizacije, ali da je riječ o procesu koji traje i često dovodi do ekstremizma, a uzroci su mnogobrojni. Mihaljević je istaknuo da je radikalizacija postupak usvajanja ekstremističkog sustava vjerovanja, uključujući spremnost za korištenje, podržavanje ili olakšavanje nasilja kao metode provođenja društvenih promjena, a neki od mogućih uzroka su osobni (npr. kognitivne funkcije pojedinca podložne za određena religijska/politička uvjerenja), politički i socioekonomski faktori (npr. društvena nejednakost), ideološki razlozi i brojni drugi. Izlaganje je završio s određenim preporukama za prevenciju koje mogu osigurati dobro upravljanje sigurnosnim okružjem pojedine zemlje poput inkluzivnosti institucija, jačanja 
osjećaja legitimnosti u javnosti, ustrajavanja na pravičnosti pravosudnog i političkog sustava, poticanja snažne međuresorne suradnje u pitanju kreiranja sigurnosne strategije, izrade okvira za delegitimizaciju ekstremista i njihovih ideologija i sl. Zaključno, Mihaljević je još jednom naglasio da je Hrvatska sigurna zemlja koja (zasad) nema problema s ekstremizmom, ali s obzirom na članstvo u Europskoj uniji mora poštovati međunarodne ugovore i dokumente nastale $\mathrm{u}$ cilju provedbe (pravosudne) politike u smjeru prevencije radikalizacije.

Posljednje predavanje održala je asistentica na projektu "Hrvatski monitor nasilja” Dalia Pribisalić, koja se dotaknula teme masovnih pucnjava u SAD-u. D. Pribisalić je odmah na početku razjasnila terminologiju masovnih pucnjava koristeći se dvjema definicijama, jednom koja je definirana kroz FBI-evu bazu podataka te kroz agenciju Gun Violence Archive. Zatim su prikazani statistički podaci o učestalosti tog fenomena na području SAD-a, uz napomenu da je 2020. godine došlo do velikog porasta masovnih pucnjava u toj zemlji. Pribisalić je navela da je od 2009. do 2018. godine u SAD-u bilo ukupno 288 slučajeva masovne pucnjave u školama, dok su za usporedbu u Kanadi i Francuskoj u istom razdoblju bila dva takva slučaja, u Njemačkoj jedan, a u Japanu, Italiji i Velikoj Britaniji nijedan zabilježen slučaj masovne pucnjave u školama. Postavila je pitanje o potencijalnim uzrocima takve slike u SAD-u i ponudila moguće odgovore kroz dvije psihološke teorije: teoriju socijalnog učenja agresije i teoriju frustracija - agresija. Potencijalni uzroci, kazala je Pribisalić, prema istraživanjima jednim dijelom sigurno leže u blagoj politici izdavanja dozvola za posjedovanje oružja, koja je specifična za SAD, uz napomenu da je bez obzira na to većina oružja koje se koristi u masovnim pucnjavama ilegalno posjedovana, pa čak i ukradena. Zaključno, priroda ovog problema, istaknula je, vrlo je kompleksna i nije lako dati jednoznačan odgovor na pitanje zašto u SAD-u ima toliko više masovnih pucnjava od ostatka svijeta i kako to prevenirati.

ESC-ova konferencija i ove je godine uspjela okupiti istraživače i pružiti kvalitetnu platformu za raspravljanje o najaktualnijim temama i predstaviti nova istraživanja i projekte te je time opravdala naslov najveće europske kriminološke konferencije s multidisciplinarnim pristupom ključnim kriminološkim temama.

Petra Šprem, mag. iur.* Dalia Pribisalić, mag. psyh.**

* Petra Šprem, mag. iur., asistentica Pravnog fakulteta Sveučilišta u Zagrebu, Trg Republike Hrvatske 14, 10000 Zagreb; psprem@pravo.hr; ORCID ID: orcid.org/0000-0003-4396-6887

** Dalia Pribisalić, mag. psych., asistentica Pravnog fakulteta Sveučilišta u Zagrebu, Trg Republike Hrvatske 14, 10000 Zagreb; dpribisalic@pravo.hr;

ORCID ID: orcid.org/0000-0001-5155-9793 